\title{
Flea Market and Thrift Facility as a Third Place with Urban-Retrofitting Approach in North Kebayoran Lama
}

\author{
Rinardy Tanuwijaya ${ }^{1}$ Rudy Trisno ${ }^{1 *}$ \\ ${ }^{1}$ Department of Architecture, Tarumanagara University, S. Parman No. 1, Jakarta 11440, Indonesia \\ *Corresponding author. Email: rudy@ft.untar.ac.id
}

\begin{abstract}
North Kebayoran Lama, Kebayoran Lama, is a sub-district in South Jakarta, which is located close to a transit hub, the Kebayoran Station. The existence of mass transportation service as a place of urban movement affects the area with the growth of new places for communities, and a third- place that was formed naturally. The place becomes unique by flea markets that sprawl among the hub, forming an image for the site, which unfortunately placed where it should not be. It becomes an irony, where a distinctive feature of a place is so potential to be developed, but also becomes the 'parasite' of the area itself. The project aims to overcome these issues with an urban retrofitting approach, to develop the area within the site, as well as the surroundings and the communities in one system, to fulfil the functions both socially and economically, but also environmental sustainability. The project is designed to be context to the surroundings, but also dynamic. So, the existence of the project doesn't become the 'alien' of the area, but the catalyst, and improves the image of the region. The design methods for the completion of the project are; 1) site and issue investigations, 2) proposals of the programs, and 3) final design descriptions, as a final result based on the programs and concepts analysis. As a conclusion, the design of the flea market and thrift facility is to provide a variety of activities, commercial areas to gather the buying and selling activities, combined with the education and entertainment programs, which also linked to the supporting functions for the transit activities. These programs make the project can be a place with diverse activities, and also a new public space at a negative point in an active urban area.
\end{abstract}

Keywords: North Kebayoran Lama, Third Place, Thrift, Transit Hub

\section{INTRODUCTION}

The growth of mass public transportations in Indonesia, especially in the Jabodetabek area, is increasing along with the rise of the economy, culture, and urban life activities. This fact is proven by the BPS - Statistics Indonesia [1], where the number of commuters in Jabodetabek is reaching 3.566.178 people, with the highest increase in the train passengers with $13.48 \%$ of growth per year. The existence of transit hubs, which become a mid-area of human movement between the first place and second place, is also participating in changing the lives of the surrounding community. Train station as a transit hub, causes the surrounding area to also develop, along with the breadwinners who appear as a reaction to the hectic human activity at the station, which also becomes a shared space, both for the commuters, and the community around.

Kebayoran Lama Utara which has a number of transit hubs, and crossed by several routes of public transportations as shown in Table 1, is not spared by this phenomenon. Kebayoran Station as an intermediary area which crowded with human movement is makes the environment around the station also adjusting itself. Raise of merchants and vendors contributing the image for the site and forming a uniqueness of the area.

Table 1 Public Transportation Routes

\begin{tabular}{|c|c|}
\hline Public Transpertations & Routes \\
\hline Electrical Rail Train & Rangkas Bitung - Tanah Abang \\
\hline \multirow[t]{6}{*}{ Bus Rupid Tranuit (Tranujakzta) } & (3) Lebak Bulua - Harmoni Sentral \\
\hline & (13) CBD Ciledug - Tendean \\
\hline & (SC) Gandaria City - Staviun Tanah \\
\hline & (3D) Blak M - Joglo \\
\hline & (9E) Pavat Kebayoeran Lama - Jelambar \\
\hline & (JAK II) Stanive Kebayeen - Seasiun Tanah Abang \\
\hline
\end{tabular}

The site is located in North Kebayoran Lama, a home of various products; from traditional markets that sell household needs, antique products or artworks, as well as second-hand clothing (Figure 1). With the various products offered, it is interesting if this potential can be used as a characteristic and image for the region.

As an area that has strong potential, North Kebayoran Lama is one of the interesting points in South Jakarta, which is even considered as an icon of Jakarta and was once rumoured to be a tourist destination. Utilization of the 
second-hand goods and flea markets can be used as a new identity for the region, also to provide a unique shopping experience. But the irony is, the sellers are not supported with adequate facilities and infrastructure, as well as the implementation of the street vendors banning regulation (Figure 2) which creates a gray area of the city. A place full of potential and stories, but placed where it shouldn't be.
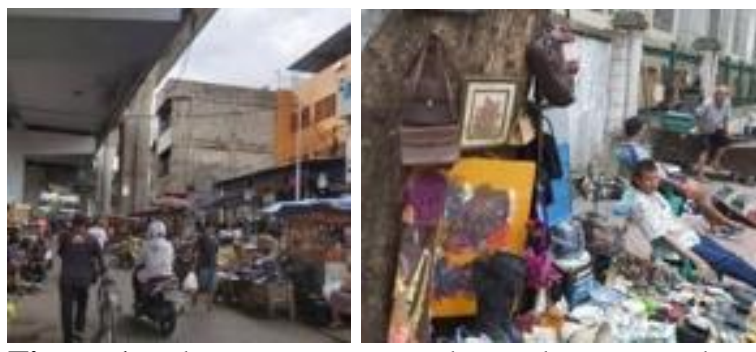

Figure 1 Kebayoran Lama Market and street vendors

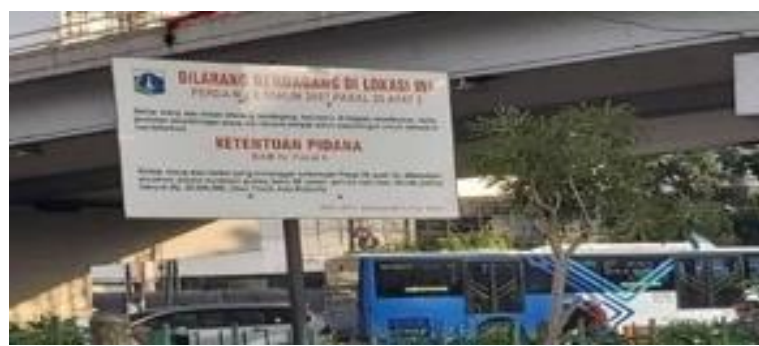

Figure 2 A sign that indicates banning of all buying and selling activity in the area

\section{METHODS}

The quality of urban space is affected by the quality of public space and the social level of the community [2]. As one of the important aspects of urban life, public space becomes important in the process of self-actualization, relaxation, and human socialization, especially in the midst of the complex urban life that keeps progressing.

As an entity that cannot be separated from human life, Hildebrand Frey [3] links the needs of the city with basic human needs (Maslow's hierarchy), which are; (1)_cities provides places for the human physical needs which are; residence (first place) and place of work (second place), (2) cities pay attention to the aspects of safety, security and protection, (3) cities create a conducive social environment, as an effort to make people able to socialize, and have a sense of belonging to the neighborhood, (4) cities give an impression, and a good reputation to their inhabitants, (5) cities can provide opportunities for people to create and express themselves, (6) city facilities are works of good design as well as the aesthetics and could give a good impression.

Based on the paragraphs above, to create a city that can meet the needs of the community, despite the house as a first place and a place to work as a second place, it also needs an 'in-between' space which can be a place where humans get other elements in basic human needs, a place to channel aspiration, and actualization, which are the third place.
Third Place based on social behavior is a neutral and informal place. A space to interact, express, think, and exchange ideas that can be used by anyone, and for any activity, as well as located between first place which is home, and second place that became a place of work. Based on The Great Good Place, third place has several characteristics as follows; [4] They are neutral, third place is a neutral area in the middle of the urban life with all its diversity and differences; They are level, third place is not exclusive and can be accessed by everyone, not limited by the differences; Conversation is the main activity; third place becomes a place to gather, meet and mingle with anyone without any restrictions; Third places are accessible, third places are places that are easily reached and not confined; Third places have regulars, third places are not becoming the aliens of the community, but welcome for all parties; Third places are physically plain and unpretentious, third- places make a sense of closeness, comforts, not suppress or intimidate; The dominant mood is playful, third place brings cheer, and could invite visitors to come again.

As a unity with the environment, the project wants to revive the image of flea markets. Based on the typology, traditional markets are one of a public space form. Visitors are free to enter and exit the market area. Markets are also a positive space, an area that is free to be visited by the community and used for positive activities. The market to be achieved is a market that still retains the traditional characteristics, which are proposing a direct trading transaction and bargaining process [5]. These elements are the main attraction that distinguishes traditional markets, with modern ones that tend to pay less attention to communication and connections between people.

The design concepts used as the basis of the project's completion is the urban retrofitting approach, as well as sustainable architecture, with the following description:

\section{Urban Retrofitting}

As one entity from the environment, the third place project is also designed in connection with Urban Retrofitting. Urban Retrofitting is basically an approach, which aims to develop areas, both within the site and the surrounding environment, and even the community within as a system, to fulfil the functions both socially and economically, and also environmental sustainability. Retrofitting is implemented to bring resilience and help the site, as well as the surroundings to grow [6].

\section{Sustainable Architecture}

In an effort to support retrofitting and local climate, the project also implements sustainable architectural methods as an approach. Sustainable Architecture itself is a concept that supports environmental sustainability, the concept of maintaining natural resources to last longer, which is associated with the age of the vital natural resources and the human ecological environment. This approach was taken in connection to the project, which emphasizes the reuse of used goods into valuable and useful items, supported by the growth of environmentally friendly trends (eco-living) in the 
community that makes the concept of reuse and recycle not only as a slogan but needs.

The sustainable design itself has several components that should be considered in order to achieve a good design, which are; energy, nature, community, material, health and well-being, and site-land use [7].

The method used to complete the project in order to create an appropriate design that makes a benefit for its users are; (1) site and issue investigations, (2) proposals of the programs, and (3) final design descriptions, as a final result based on the programs and concepts analysis.

\section{RESULT AND DISCUSSION}

\subsection{Site and Issue Investigations}

Based on the data, the selected site is located on Kebayoran Lama Rd., North Kebayoran Lama, South Jakarta 12220 (Figure 3). The site is also located close to the Kebayoran Station as a transit hub, and the Pasar Kebayoran Lama Transjakarta bus stop, which causes the area to become a lively spot for human activities, especially with the fact that it's also close to the Kebayoran market and a complex of shophouses. Thus, the site became a meeting place for various kinds of communities, so are traders or sellers, buyers, residents around, and also commuters.
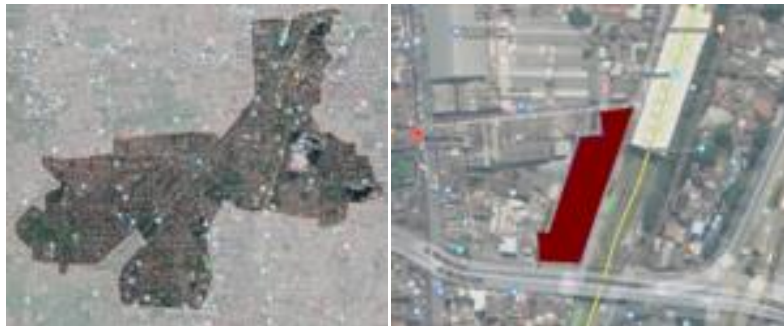

Figure 3 Site location

The existing site itself is located on a ground that still has buildings above it, which are abandoned and unused shophouses (Figure 4). With so many unused areas on the site, the site is widely used as a selling area for street vendors, as well as an unauthorized waste disposal site which actually becomes a problem in the environment around the site.

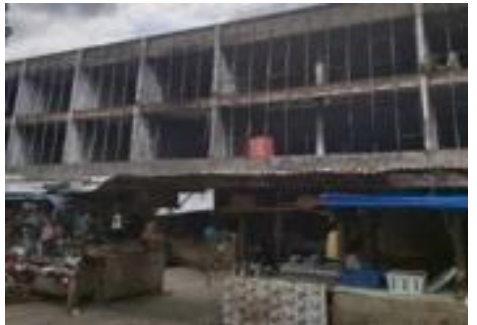

Figure 4 Selected site condition
The street stalls and vendors are increasingly crowded on Saturdays and Sundays, covering the sidewalks and roads that actually make a unique attraction, but not supported by adequate facilities and infrastructure. Moreover, the potentials are not in accordance with the applicable regulations. It becomes an irony, where something that is so characteristic and supports the activities in the area, is also becoming something that shouldn't be there in the first place.

The project as a third place is proposed to be a place for the community, which designed as a place not only for work, but socialize, both for the flea market vendors and the community among it, to create a healthier place in the context of urban space, and a bridge to create a better neighborhood, which not only has high tourism potential but also as a 'center'.

\subsection{Programs Proposal}

The site is a busy and active spot of the urban area, as well as a gathering place for various communities, especially the marker vendors or traders, buyers, residents, and the commuters. In connection with this, the program is made to be able to accommodate the various layers of society, as well as develop the characteristics of the site and the regional commodities. Based on this, the program is then divided into four main pillars, which are; commercial as a place for trades; education as an educational media both for the surrounding community and commuters, especially in terms of emphasizes the used of second-hand products; edutainment, as an entertainment, and meeting space for the communities and the general public; as well as supporting programs as a program to support the commuter's needs in their transit.

As part of the environment, building is not an 'alien' that stands alone in the environment, but also requires the connection and role of the surrounding communities, to create a better space for human activity. North Kebayoran Lama, as the home of various industries has a protracted waste problem. The absence of landfills around the area forces both residents and traders to litter the garbage not in the right place (Figure 5).

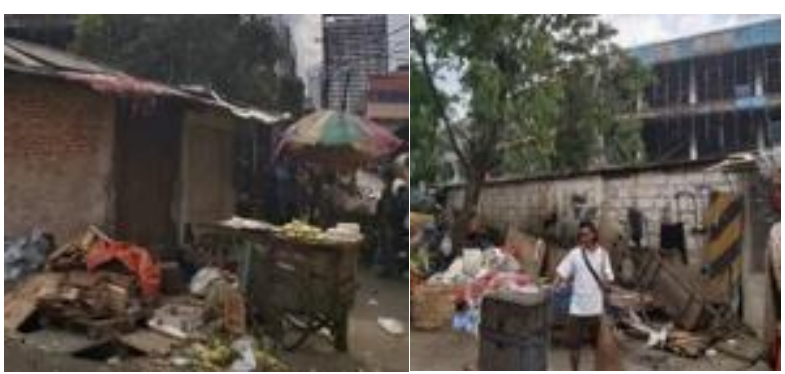

Figure 5 A pile of trash located around the site

As a one entity with the surrounding community, the program also has a role to solve the area's problems. With the existence of the project in the area, the project wants to create a program that involves the community in a reciprocal relationship on the site. The program wants to 
invite the community to be able to distribute inorganic waste, to be used as workshop materials, installation and facade materials, or processed into more valuable items to be resold by the traders.

\subsection{Design Descriptions}
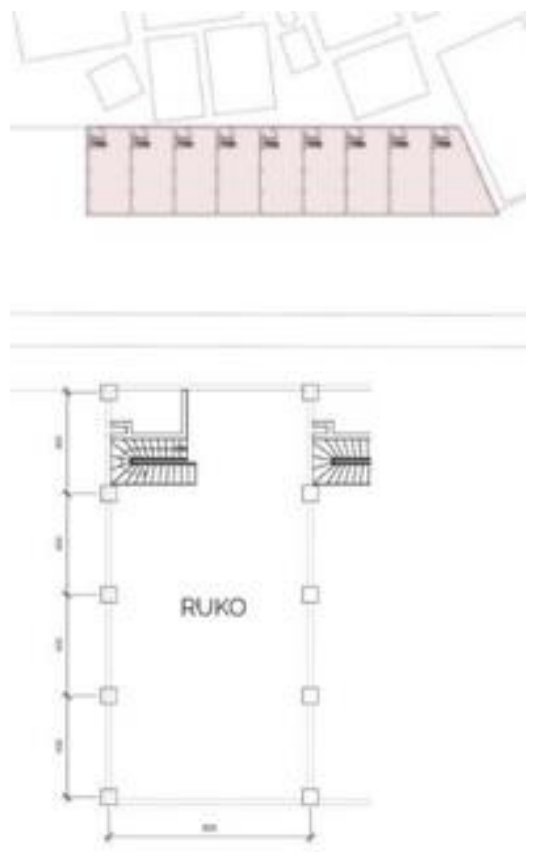

Figure 6 Existing shophouses plan

The building is designed with the mass which is inspired by the surrounding urban pattern, where the functions of each building form an image of the city. This is depicted in the design, where a building is also formed by the functions of the space in them, which are imaged in geometric shapes that accumulate and form the building. The building tries to be in harmony and context with the surroundings which are shophouses and houses but still presents the dynamic side, to illustrates the impression of the randomness of a 'flea market', so that the existence of the project does not become an alien in the area but becomes a catalyst, to improve the image of the site. Sustainable as a concept is also promoted as a response from the building, both to the environment and the surrounding communities. Combined with the urban retrofitting approach, which aims to develop areas both within the site and the surrounding environment, as well as the people in one system. The building utilizes the structure of the existing shophouses (figure 6) not only to save cost, but also as a way to reduce construction wastes which becomes a problem not only around the site, but the capital DKI Jakarta. The application of adaptive reuse itself has several benefits, which are [8];

1. Supporting conservation and resource saving strategies.

2. Relatively lower construction costs.

3. Short processing time.

4. The cost of acquiring the land is quite light.
Recycled materials which mainly come from the market or the surrounding households are also used as the facades or other accents in the building as shown in Figure 7.

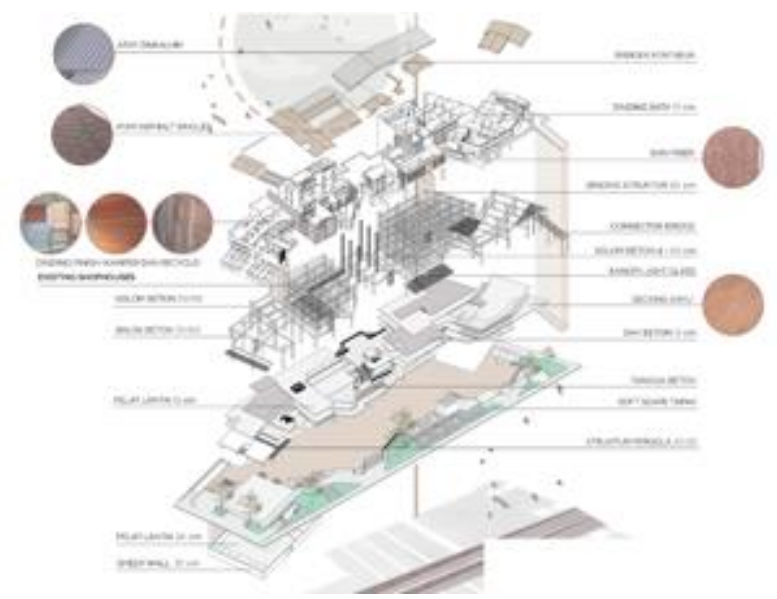

Figure 7 Design's structural axonometric

The exterior of the building is designed to be context and still maintains harmony with the surrounding environment, which are the shophouses and local's houses, but also dynamic, giving a characteristic for the building and forming the image for the site. The design was also made to give the impression of openness and permeability, either with a facade that maximizes openings to implement the concept of openness, symbolizing a third place where the community gathers [9], or with the existence of a staircase that directly connects the outside and the inside areas of the building, as well as direct access from the outdoor space to another floor in the building. With the openness of the facade, natural lighting and cross-ventilation can be maximized, so that air circulation in the building can run well as a way to make the building more sustainable [10]. Stair area is also made as a public space that is integrated with the outdoor space of the building, which is designed in harmony with the mass of projects that are made as open as possible, to maximize the concept of openness, for a third place. The design of the building will be shown by the exterior and interior shots as shown in the Figure 8 and Figure 9.

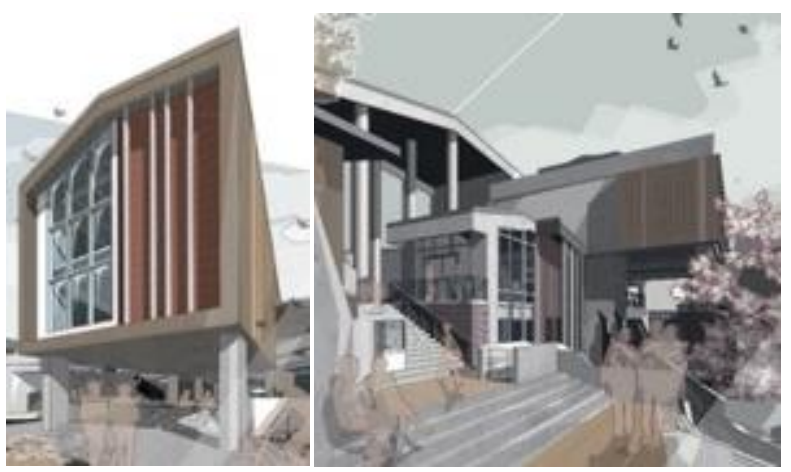




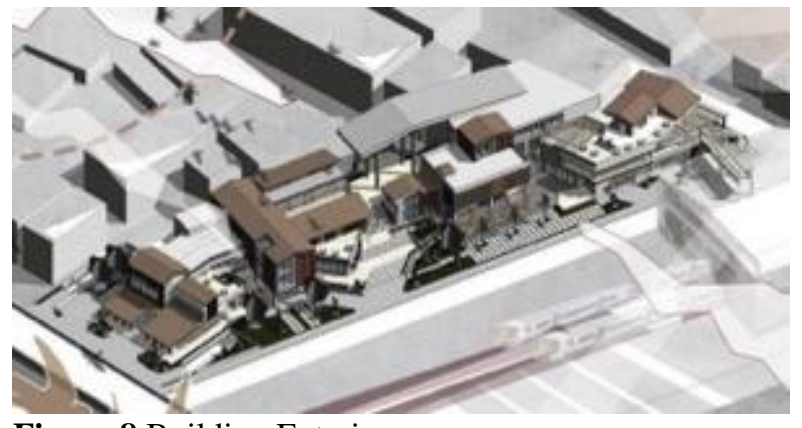

Figure 8 Building Exteriors

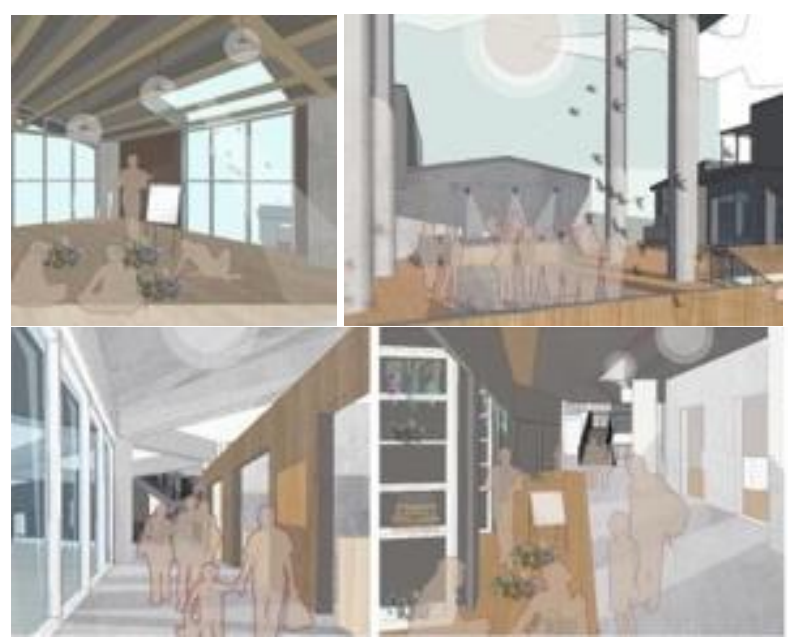

Figure 9 Building Interiors

\section{CONCLUSIONS}

The project was presented as a reaction to the needs and the problems of the site, which in North Kebayoran Lama. The site which is close to Kebayoran Station as a transit hub causes the presence of various communities to gather around it. The appearance of flea market stalls and street vendors was a reaction to the hectic activity in the area, which took part in shaping the image of the site, but was not supported by adequate facilities and suitable locations. The project as a third place is trying to accommodate this phenomenon, besides being a meeting point and an activity place for various kinds of people, in the midst of busy urban activities that bridge the first place and second place, but also a media for flea and thrift vendors around the site to get a place which is more appropriate and adequate, while also enhancing the image of the region.

Building's design as a third place is obtained by theories, data, analysis, and related design methods, to produce a good and effective design. Urban retrofitting methods and sustainable architecture are used as a reference, which then followed by the design method which are; site and issues investigations, as well as the application of design and program concepts as a solution to the issues, to make a complete overall design, which can solve the problems around the site, while fulfilling the needs of third place as one of the basic human needs.

\section{ACKNOWLEDGMENT}

Thank you to LPPM-UNTAR (Lembaga Penelitian dan Pengabdian Kepada MasyarakatUniversitas Tarumanagara) for funding this research.

\section{REFERENCES}

[1] Badan Pusat Statistik Provinsi DKI Jakarta, Statistik Transportasi DKI Jakarta, DKI Jakarta, 2018.

[2] E. Darmawan, Ruang Publik Dan Kualitas Ruang Kota, 2005.

[3] H. W. Frey, Designing The City, Towards A More Sustainable Urban Form, E \& FN SPON, 1999.

[4] R. Oldenburg, The Great Good Place, Cambridge: De Capo Press, 1997.

[5] H. Malano, Selamatkan Pasar Tradisional: Potret Ekonomi Rakyat Kecil, Jakarta: Gramedia Pustaka Utama, 2011.

[6] J. Williamson and E.D. Jones, Retrofitting Suburbia: Urban Design Solutions for Redesigning Suburbs, John Wiley \& Sons Inc, 2009.

[7] P. Sassi, Strategies for Sustainable Architecture, Routledge, 2015.

[8] R. Sofiana, A. Purwantiansing, Anisa, "Strategi Penerapan Konsep Adaptive Reuse pada Bangunan Tua Studi Kasus: Gedung PT P.P.I (Ex. Kantor PT Tjipta Niaga) di Kawasan Kota Tua Jakarta," in Seminar Nasional Sains dan Teknologi, Fakultas Teknik Universitas Muhammadiyah Jakarta, 2014.

[9] R. Trisno and F. Lianto, "Realization of Hybrid Concept and Symbiosis in Green Open Space (RTH) at Housing Complex RW (Neighborhood Council) Pluit, Jakarta Utara, Indonesia," Journal of Physics: Conference Series, vol. 1179, pp. 1-6, 2018.

[10] B. Chandra, R. Trisno, S. Gunanta, N. Widayati and F. Lianto, "The Application of Passive Design Chart on the Analysis of Natural Ventilation of Low and Middle Income Flats Case Study Sky View Apartment and 'Rusunawa' Manis Jaya, Tangerang," Journal of Physics: Conference Series, vol. 1179, pp. 1-9, 2019. 